\title{
The Effectiveness of Motivational Strategies on Productivity in Selected Financial Institutions in Nigeria
}

\author{
Mofoluke Omilani, Morakinyo Akintolu \\ Department of Adult Education, University of Ibadan, Ibadan, Nigeria \\ Email: mofolukeabidemi@gmail.com, akintolumorakinyo@yahoo.com
}

\begin{abstract}
How to cite this paper: Omilani, M. and Akintolu, M. (2017) The Effectiveness of Motivational Strategies on Productivity in Selected Financial Institutions in Nigeria. American Journal of Industrial and Business Management, 7, 881-892.

https://doi.org/10.4236/ajibm.2017.77062
\end{abstract}

Received: June 22, 2017

Accepted: July 4, 2017

Published: July 7, 2017

Copyright $\odot 2017$ by authors and Scientific Research Publishing Inc. This work is licensed under the Creative Commons Attribution International License (CC BY 4.0).

http://creativecommons.org/licenses/by/4.0/

\begin{abstract}
This study examined the effectiveness of motivational strategies on productivity, with reference to First Bank of Nigeria and Union Bank of Nigeria employees. The study adopted the descriptive survey research design. The findings revealed that there is positive relationship between motivational strategies and employees' productivity. The result demonstrated that The financial strategies available to employees are leave allowances, bonus and fringe benefits paid when due, availability and accessibility of medical insurance, pension fund scheme and the non-financial strategies are promotions as at when due, training and friendly work environment contribute immensely to high productivity of employees. The finding indicated that motivational strategies have significant influence on productivity of workers as it makes workers put in their best always, and manage to use it as a tool to motivate and increase productivity, and influences workers' attitude towards work doing impact on the morale of workers and helps workers put in their best. There is a significant effect of promotion, allowances and benefits medical insurance scheme, pension fund scheme, work environment on productivity. Motivational strategies in the workplace enhance high level of productivity. The following recommendations were made; the management needs to improve salaries, benefits from time to time and improve the working condition of workers. Also give a sense of recognition, belongingness, chance to contribute and flexibility in approaches to conflicts with the workers.
\end{abstract}

\section{Keywords}

Motivation, Strategies, Productivity, Financial Institutions

\section{Introduction}

Overtime, what work means as well as the motives that induce people to work 
have changed considerably. The complexity embedded in the motive and what work means have been realized. Money as an incentive is just a part of what motivates a man to work, just for basic survival. Most manual work was performed by slaves, and the Greeks had distaste for work and believed that work was a "curse" [1]. While the early Christians believed work to be God's punishment for the original sin committed by Adam, work was also believed to be drudgery by Hebrews.

By the end of $19^{\text {th }}$ century, industrialists assumed that competition was the way of life and their success could be attributed to their capability to manage the complexity of organization. In the early $20^{\text {th }}$ century, the concept of "Scientific Management" came into existence through Frederick Winslow Taylor who applied scientific methods to industry (although some early innovators preceded him). In his approach he approved beyond any reasonable doubt that a worker will put in more effort if he is rewarded economically. Essentially, one may ask for what factors are connected with a situation which provides individual satisfaction and productivity over and above marginal subsistence and performance.

The concept of industrial development in Nigeria cannot but be examined. The most important characteristic of industrialization is the predominance of wage earners within the labour force.

The growth of wage earning population has proceeded with political, social and economic growth of the country. The average Nigerian is free to decide on take up wage employment or set up his own trade with the emergence of urbanization, and the average Nigerian is engaged in one of the modern occupations. With the increase in demand, there was an increase in revenue which in turn led to the expansion of public health and education services which are prerequisites to economic development.

However, due to the rapidity in the growth of social and economic change, many Nigerians were employed in the various fields of human endeavour. These workers found themselves in a different environment requiring different attitudes and approaches to socio-economic life often resulting into moving from their homes to larger commercial centers. Nigerians found themselves in a different world-a different environment requiring different ways of behaviour which also resulted in moving from rural areas to large commercial industrial centers. The working group became an accepted norm, this led to improvement in standard of living. The world of work cannot prosper without human efforts and material resources. When an industry is established, the entrepreneur aims at providing certain goods or services on which he would expect some returns. The returns can only be made possible by the workers engaged in the establishment. The human element is very vital to the growth of any establishment. People are needed to utilize the available resources. Hence there is a need to employ and motivate the workers.

Today, the world of work is facing so many challenges among which are the changing requirements of work, the conditions of work, changes in employees, grievances, changes in technology, complexity of management, social and indus- 
trial changes, economic fluctuation, changes in the family set up, changes in political structure with their effects on industry among others. These changes are not without implications for industry and where the minds of the employees are not prepared for these changes, there may be adverse effects on industry [2].

Motivation, according to [3], refers to "the reasons underlying behaviour". Paraphrasing [4] broadly define motivation as "the attribute that moves us to do or not to do something". Intrinsic motivation is motivation that is animated by personal enjoyment, interest or pleasure. As [5] observed, "intrinsic motivation energizes and sustains activities through the spontaneous satisfactions inherent in effective volitional action. It is manifested in behaviour such as play, exploration, and challenge seeking that people often do for external rewards". [6] clarifies motivation as against manipulation. According to him "motivation is not about manipulation but is all about the need which prompts people to do things and providing ways of helping them to satisfying those needs through the management”. In its simplest form, motivation implies a stimulus to action inciting to action or promoted by the deliberate enticement of something. After recruiting trained, compensated and appraised staffs of an organization, what will an organization do to retain her staff for a long period of time? It is believed by human relations exponents that people will continue to contribute to the effective and economical accomplishment of the organization if they are adequately motivated. All human beings have needs and all strive to satisfy these needs. Some needs are basic and must be satisfied, all strive to satisfy these needs may never be satisfied. The point at which each of our needs are satisfied differ from person to person.

Motivational strategies are important in offering new ideas for running expanding organizations and motivation insures that employees will work hard enough to see these ideas through to success [7]. To some extent, a high level of employee motivation is derived from effective management practices. To develop motivated employees a manager must treat people as individuals, empower workers, provide an effective reward system, redesign jobs and create a flexible work place.

Motivational incentives are driving forces which compel a worker to be dedicated and diligent in his/her work. It is a drive to satisfy an unsatisfied need. It encourages people to achieve goals, influence output and helps to achieve organizational objectives. A well-motivated worker will perform optimally and increase his/her productivity.

Productivity in general has been defined in the Cambridge International and Oxford Advance Learner's dictionaries as the rate at which goods are produced with reference to number of people and amount of materials necessary to produced it. On the other hand, productivity have been defined as the relation between output and input, has been available for over two centuries and applied in many different circumstances on various levels of aggregation in the economic system. It is argued that productivity is one of the basic variables governing economic production activities, perhaps the most important one. However, at 
the same time as productivity is seen as one of the most vital factors affecting a manufacturing company's competitiveness, researchers argue that productivity is often relegated to second rank, and neglected or ignored by those who influence production processes [8]. The definition of productivity is applied by economists at the industrial level to determine the economy's health, trends and growth rate whiles at the project level, it applies to areas of planning, cost estimating, accounting and cost control [9].

Productivity is how efficiently a certain output of goods and services are produced or rendered and the value created by the production process [10]. It is a ratio of how well an organization converts input in form of resources labour, material, machinery into goods and services. Enhancing productivity and working conditions in organization is enhancing individual and collective capabilities in a systematic and permanent way. It is a proved fact that a comfortable worker is a productive worker, improved working conditions can be achieved using the right motivational incentives. It is based on the forgoing that this present study dwelt on the effectiveness of motivational strategies on productivity in selected financial institutions in Nigeria.

Motivational strategies have been considered as a very important tool in enhancing workers efficiency, productivity and organizational goals. In public enterprises, most of the employees are well compensated while in the private enterprises the management is expecting the best output from well not compensated employees, inspite of the efforts and the commitment of employees in their workplace. Most often, workers feel abused, unappreciated and the work environment is ill-equipped by the organization. Stressful work conditions, ever increasing demands and layoffs are sometimes experienced by these workers. Workers are the productive cadre of any organization and they know the financial capacity of their organization. The management wants to maximize profits while the employees want good incentives to motivate them. The failure of the management to give incentives to workers result in less productivity which also affects the organizational goals.

Towards this trend the main objective of this study is to examine the effectiveness of motivational strategies on productivity in some selected financial institutions in Oyo State, Nigeria. While the specific objectives of this study are to:

1. Assess the financial and non-financial strategies available to employees in First Bank of Nigeria and Union Bank of Nigeria.

2. Ascertain the impact of motivational strategies on workers' productivity.

3. Examine the differences in motivational packages available to junior and senior workers.

4. Examine the problems associated with workers motivational strategies.

5. Assess the view of the management towards workers motivational strategies.

The following Research Questions guided the study so as to provide solutions to the problems of the study:

1. What are the financial and non-financial strategies available to the employees in the selected private enterprises? 
2. What are the impacts of motivational strategies on worker's productivity?

3. What are the motivational packages available to junior and senior workers? In the study the following Hypothesis were tested:

1. There is no significant difference in the motivational packages available to junior and senior bank staff.

2. There is no significant difference in work place productivity of bank staff.

\section{Structure of Research}

At first the study provides background information about motivation and productivity importance on employee effectiveness. The statement of problem, research question, research hypothesis and significant of the study was also included. After which theories of motivation were discussed according to different authors. The study also provides information about the research methodology implemented for this study. The last phase presents procedure and findings of research, its conclusion, offers recommendation for future research in the area of motivation and productivity of employees.

\section{Theoretical Framework}

Maslow's model [11], is a general one in which all needs interact with each other to some degree. Individuals advance up the hierarchy as each lower level need becomes satisfied. Therefore, to provide motivation for a change in behaviour, the manager must direct attention to the next higher level of needs that seek satisfaction. Management must provide an opportunity to satisfy these needs through creating a physical and conceptual work environment, so that people will be motivated to achieve organizational goals.

The Herberg's two factor theory is tied with Maslow's basic model and provides directions and incentives that tend to satisfy these needs. Workers are highly motivated by financial rewards, organized supervision, well defined work rules, pleasant work environment and positive employee interaction and do not give much importance to achievement and self-actualization. According to [12], this creates room for job enrichment which also promotes freedom of operation and responsibility.

[13] expectancy model, assumes that motivation to work is strongly determined by an individual's perception that a certain type of behaviour will lead to a certain type of outcome and his personal preference for that type of outcome. The management must investigate the desirability of the rewards which are given on the basis of performance. Monetary benefits may be more desirable for some workers, the need to be formally appreciated may be more valuable rewards for others for similar task oriented activities.

There is need for the management to provide opportunities for training to improve skills in order to improve the relationship between effort and performance. The performance appraisal methods and the associated performance rewards may not be equitable. The management must re-evaluate the appraisal techniques and formulate policies that strengthen performance reward relation- 
ship as just and equitable.

The incentive theory of motivation, not all incentives is created equal and the rewards that motivate a person might not be enough to inspire another person to take action. Physiological, social and cognitive factors can play a role in which incentives can motivate. The value of an incentive can change over time and in different situation. Incentives only become powerful if the individual places importance on the reward.

On this background the study would be of significant in the areas where there are problems among employees and thus would be of great benefit to the management and policy makers in general. Also, serves as blueprint for industrialists in the private sectors, the general public and the government. Finally, the findings would help in human resources practices.

\section{Methodology}

The researched employed is descriptive survey research design. This method was adopted because it helps to describe, record, analyse and interpret the conclusion that exists in the study. The population of the study comprises of the junior, senior and management staff of the regional head offices of First Bank of Nigeria and Union Bank of Nigeria in Ibadan, Oyo State. First Bank of Nigeria with one hundred and twenty five (125) and Union Bank of Nigeria with one hundred and seventeen (117) staff. A total population of two hundred and forty two (242) members of staff in both organizations. However, purposive sampling technique was used to select eighty (80) respondents for the study from each organization. A total of one hundred and fifty (150) respondents were selected from both organizations. Thirty management staff, seventy senior staff and fifty junior staff was selected. The questionnaires were administered on employees found at their duty posts directly at the regional head offices used for the study.

The instrument adopted for the data collection in this study is questionnaire tagged Motivational Strategies on Productivity Scale (MSPS). It is purposely design to elicit information from the staff of First Bank of Nigeria and Union Bank of Nigeria, Ibadan.

The questionnaire consists of two parts; one part was made up of demographic data to obtain information on variables such as age, sex, educational qualification, occupational status cadre, length of service and department. The second part was made of some structured questions with the intention of testing the research hypotheses designed for this study. The question items were constructed on a four likert scale which is as follows: Strongly Agree, (SA) Agree (A), Disagree (D) and Strongly Disagree (SD).

The face and content validity of the instrument was determined through experts opinions in the field from the faculty and the researcher's Supervisor who critically scrutinized the different items contained in the instrument, suggestions and amendments were made. The reliability test and re-test method was adopted to establish the reliability of the instrument. The tests yielded agreeable result which confirmed the reliability of the instrument, through a pilot study con- 
ducted with twenty (20) randomly selected respondents from Princeton Health Limited, Ibadan who were not part of the study. The result of $r=0.69$ confirmed the accuracy of the instrument. Analysis of this study was done through the use of simple percentages, frequency counts and inferential statistics of ANOVA, Chi-Square and Multiple Regression analysis which was used as parameter for the analysis of data for the validation or rejection of the research hypotheses.

\section{Analysis of Research Question}

\section{Research Question 1: What are the financial and non-financial strategies available to employees in First Bank of Nigeria and Union Bank of Nigeria?}

Table 1 showed that 98 (65.3\%) respondents agreed that leave allowance, bonus and other benefits are paid as at when due while $52(34.7 \%)$ respondents disagreed, $124(82.7 \%)$ respondents agreed that there is availability and accessibility of medical insurance scheme to employees while 26 (17.3\%) respondents disagreed, $120(80.0 \%)$ respondents agreed that pension scheme is available to all staff while $3(20.0 \%)$ respondents disagreed, 128 (74\%) respondents agreed that bonus and fringe benefits are readily available to employees, $111(74.0 \%)$ respondents agreed that employees are promoted as at when due while $39(26.0 \%)$ respondents disagreed, $107(71.3 \%)$ respondents agreed that training is encouraged when due while $43(28.6 \%)$ respondents disagreed and $114(76.0 \%)$ respondents agreed that working environment provided by the organization is friendly to the worker while $36(24.0 \%)$ respondent disagreed.

The finding indicated that the financial strategies available to employees in First bank Nigeria and Union Bank of Nigeria are, leave allowances, bonus and

Table 1. Frequency distribution of financial and non-financial strategies available to employees of first bank of Nigeria and union bank of Nigeria.

\begin{tabular}{|c|c|c|c|c|c|c|}
\hline $\mathrm{s} / \mathrm{n}$ & Statements & SA & A & $\mathrm{D}$ & $\mathrm{SD}$ & Total \\
\hline 1 & $\begin{array}{l}\text { Leave allowances, bonus are } \\
\text { paid as at when due } \\
\text { (maternity, paternity, study) }\end{array}$ & $\begin{array}{c}44 \\
29.3 \%\end{array}$ & $\begin{array}{c}54 \\
36.0 \%\end{array}$ & $\begin{array}{c}20 \\
13.3 \%\end{array}$ & $\begin{array}{c}32 \\
21.3 \%\end{array}$ & $\begin{array}{c}150 \\
100.0 \%\end{array}$ \\
\hline 2 & $\begin{array}{l}\text { There is availability and } \\
\text { accessibility of medical insurance } \\
\text { scheme to employees }\end{array}$ & $\begin{array}{c}73 \\
48.7 \%\end{array}$ & $\begin{array}{c}51 \\
34.0 \%\end{array}$ & $\begin{array}{c}20 \\
13.3 \%\end{array}$ & $\begin{array}{c}6 \\
4 \%\end{array}$ & $\begin{array}{c}150 \\
100.0 \%\end{array}$ \\
\hline 3 & $\begin{array}{l}\text { Pension fund scheme is } \\
\text { available to all staff }\end{array}$ & $\begin{array}{c}50 \\
33.3 \%\end{array}$ & $\begin{array}{c}70 \\
46.7 \%\end{array}$ & $\begin{array}{c}10 \\
6.7 \%\end{array}$ & $\begin{array}{c}20 \\
13.3 \%\end{array}$ & $\begin{array}{c}150 \\
100.0 \%\end{array}$ \\
\hline 4. & $\begin{array}{l}\text { Bonus and fringe benefit } \\
\text { are readily available }\end{array}$ & $\begin{array}{c}60 \\
40 \%\end{array}$ & $\begin{array}{c}68 \\
45.3 \%\end{array}$ & $\begin{array}{l}12 \\
8 \%\end{array}$ & $\begin{array}{c}10 \\
6.7 \%\end{array}$ & $\begin{array}{c}150 \\
100.0 \%\end{array}$ \\
\hline 5 & $\begin{array}{c}\text { Employees are promoted } \\
\text { as at when due }\end{array}$ & $\begin{array}{c}44 \\
29.3 \%\end{array}$ & $\begin{array}{c}67 \\
44.7 \%\end{array}$ & $\begin{array}{c}19 \\
12.7 \%\end{array}$ & $\begin{array}{c}20 \\
13.3 \%\end{array}$ & $\begin{array}{c}150 \\
100.0 \%\end{array}$ \\
\hline 6 & $\begin{array}{l}\text { Training is } \\
\text { encouraged when due }\end{array}$ & $\begin{array}{c}42 \\
28 \%\end{array}$ & $\begin{array}{c}65 \\
43.3 \%\end{array}$ & $\begin{array}{c}22 \\
14.6 \%\end{array}$ & $\begin{array}{c}21 \\
14 \%\end{array}$ & $\begin{array}{c}150 \\
100.0 \%\end{array}$ \\
\hline 7 & $\begin{array}{l}\text { Working environment } \\
\text { provided by the organization } \\
\text { is friendly to the work }\end{array}$ & $\begin{array}{c}63 \\
42.0 \%\end{array}$ & $\begin{array}{c}51 \\
34.0 \%\end{array}$ & $\begin{array}{c}16 \\
10.7 \%\end{array}$ & $\begin{array}{c}20 \\
13.3 \%\end{array}$ & $\begin{array}{c}150 \\
100.0 \%\end{array}$ \\
\hline
\end{tabular}


fringe benefits paid when due, availability and accessibility of medical insurance, pension fund scheme and the non-financial strategies are promotion as at when due, training and friendly work environment.

Research Question 2: What is the impact of motivational strategies on worker's productivity?

Table 2 showed that $94(62.7 \%)$ respondents agreed that motivational strategies makes workers pout in their best always while $56(37.3 \%)$ respondents disagreed $80(53.3 \%)$ respondents agreed that fat salaries are best tools with which management use to motivate and increase productivity while $70(46.7 \%)$ respondents disagreed 88 (58.7\%) respondents agreed that motivational strategies influence workers attitude towards work done while $62(41.3 \%)$ respondents disagreed, $85(56.7 \%)$ respondents agreed that motivational strategies impact on the morale of workers at work while 65 (43.3\%) respondents agreed that motivational strategies help workers to meet their needs while 75 (50\%) respondents disagreed. The $\mathrm{x}^{2}$ value of 47.11 is greater than the table value of 12.07 at 0.05 level of significance.

The finding indicated the motivational strategies that have significant influence on productivity of workers as it makes worker put in their best always, management use it as a tool to motivate and increase productivity, influence workers attitude towards work done impact on the morale of workers and helps workers to meet their needs.

Research Question 3: What are the problems associated with workers motivational strategies?

Table 2. Chi-square analysis showing the impact of motivational strategies on worker's productivity.

\begin{tabular}{|c|c|c|c|c|c|c|c|c|c|c|}
\hline $\mathrm{N}$ & Statement & SA & A & $\mathrm{D}$ & SD & $\mathrm{x}^{2} \mathrm{cal}$ & df & $\mathrm{x}^{2}$ crit & $\mathrm{P}$ & RMC \\
\hline 1 & $\begin{array}{c}\text { Motivational strategies } \\
\text { makes workers put } \\
\text { in their best always }\end{array}$ & $\begin{array}{c}44 \\
29.3 \%\end{array}$ & $\begin{array}{c}50 \\
33.3 \%\end{array}$ & $\begin{array}{c}20 \\
13.5 \%\end{array}$ & $\begin{array}{c}36 \\
24.0 \%\end{array}$ & & & & & \\
\hline 2 & $\begin{array}{l}\text { Fat salaries are best } \\
\text { tools with which } \\
\text { management use to } \\
\text { motivate and increase } \\
\text { productivity }\end{array}$ & $\begin{array}{c}39 \\
26.0 \%\end{array}$ & $\begin{array}{c}41 \\
27.3 \%\end{array}$ & $\begin{array}{c}37 \\
24.7 \%\end{array}$ & $\begin{array}{c}33 \\
22.0 \%\end{array}$ & & & & & \\
\hline 3. & $\begin{array}{l}\text { Motivational strategies } \\
\text { influences workers } \\
\text { attitude towards } \\
\text { work done }\end{array}$ & $\begin{array}{c}39 \\
26.0 \%\end{array}$ & $\begin{array}{c}49 \\
32.6 \%\end{array}$ & $\begin{array}{c}30 \\
20.0 \%\end{array}$ & $\begin{array}{c}32 \\
21.3 \%\end{array}$ & 47.11 & 12 & 12.07 & 0.15 & sig \\
\hline 4. & $\begin{array}{l}\text { Motivational strategies } \\
\text { impact on the } \\
\text { morale strategies } \\
\text { impact on the morale } \\
\text { of workers at work. }\end{array}$ & $\begin{array}{c}30 \\
20.0 \%\end{array}$ & $\begin{array}{c}55 \\
36.6 \%\end{array}$ & $\begin{array}{c}34 \\
22.6 \%\end{array}$ & $\begin{array}{c}31 \\
20.7 \%\end{array}$ & & & & & \\
\hline 5. & $\begin{array}{l}\text { Motivational strategies } \\
\text { helps workers to } \\
\text { meet their needs }\end{array}$ & $\begin{array}{c}37 \\
24.7 \%\end{array}$ & $\begin{array}{c}38 \\
25.3 \%\end{array}$ & $\begin{array}{c}33 \\
22.0 \%\end{array}$ & $\begin{array}{c}42 \\
28.0 \%\end{array}$ & & & & & \\
\hline
\end{tabular}


Table 3 showed that $95(63.3 \%)$ respondents agreed that favourism is a problem associated with workers motivated strategies while 55 (36.7\%) respondents disagreed, $93(62.0 \%)$ respondents agreed that bad management is a problem associated with motivational strategies while 57 (38.0\%) respondents disagreed, $98(65.3 \%)$ respondents agreed that insincerity is a problem associated with motivational strategies while 52 (34.7\%) respondents disagreed, 103 (68.7\%) respondents agreed that motivational tools are not properly provided while 47 (31.3\%) respondents disagreed 85 (56.7\%) respondents agreed that indiscriminate use of incentives to motivate worker is a problem associated with motivational strategies wile 65(43.3\%) respondents disagreed.

The finding showed that the problems associated with motivational strategies are favourism, bad management, insincerity, motivational strategies are not properly provided and indiscriminate use of incentives to motivate workers.

Research Question 4: What is the management view towards workers motivational productivity?

Table 4 showed that $43(28.7 \%)$ agreed that management see as a way to motivate junior staff, $40(26.7 \%)$ agreed that management see motivational strategies a way of encourage workers commitment to work, $37(24.7 \%)$ agreed that management see motivational strategies as tools for enhancing productivity, 30

Table 3. Frequency distribution of responders view on the problems associated with workers motivational strategies.

\begin{tabular}{|c|c|c|c|c|c|c|}
\hline $\mathrm{N}$ & Statement & SD & A & $\mathrm{D}$ & SD & Total \\
\hline \multirow{2}{*}{1.} & \multirow{2}{*}{ Favourism } & 55 & 40 & 20 & 35 & 150 \\
\hline & & $36.7 \%$ & $26.7 \%$ & $13.3 \%$ & $23.3 \%$ & $100.0 \%$ \\
\hline \multirow{2}{*}{2.} & \multirow{2}{*}{ Bad Management } & 60 & 33 & 40 & 17 & 150 \\
\hline & & $40.0 \%$ & $22.0 \%$ & $26.7 \%$ & $11.3 \%$ & $100.0 \%$ \\
\hline \multirow{2}{*}{3.} & \multirow{2}{*}{ Insincerity } & 49 & 49 & 30 & 32 & 150 \\
\hline & & $32.7 \%$ & $32.7 \%$ & $20.0 \%$ & $21.3 \%$ & $100.0 \%$ \\
\hline \multirow{2}{*}{4.} & Motivational strategies & 53 & 50 & 22 & 25 & 150 \\
\hline & not property provided & $35.3 \%$ & $33.3 \%$ & $14.7 \%$ & $16.7 \%$ & $100.0 \%$ \\
\hline \multirow{2}{*}{5.} & Indiscriminate use of & 40 & 45 & 30 & 35 & 150 \\
\hline & incentives to motivate workers & $26.7 \%$ & $30 \%$ & $30 \%$ & $23.3 \%$ & $100.0 \%$ \\
\hline
\end{tabular}

Table 4. Frequency distribution of respondents view on management towards workers productivity.

\begin{tabular}{|c|c|c|c|}
\hline $\mathbf{S} / \mathbf{N}$ & Statement & Frequency & Percentage \\
\hline 1 & $\begin{array}{c}\text { Management see motivational strategies as } \\
\text { a way to motivate junior staff }\end{array}$ & 43 & 28.7 \\
\hline 2. & $\begin{array}{c}\text { Management see motivational strategies as } \\
\text { way to encourage workers commitment to work }\end{array}$ & 40 & 26.7 \\
\hline 3. & $\begin{array}{l}\text { Management see motivational strategies as } \\
\text { tools for enhancing productivity }\end{array}$ & 37 & 24.7 \\
\hline \multirow[t]{2}{*}{4.} & $\begin{array}{l}\text { Management see motivational } \\
\text { strategies for achieving organizational goals }\end{array}$ & 30 & 20.0 \\
\hline & Total & 150 & 100.00 \\
\hline
\end{tabular}


(20.0\%) agreed that management see motivational strategies for achieving organizational goals.

The finding showed that respondent agreed that management view motivational strategies as way to motivate junior staff, encourage workers to be committed to work, enhancing productivity and for achieving organizational goals.

\section{Hypotheses Testing}

Hypothesis 1: There is no significant difference in the motivational packages available to junior and senior bank staff.

Table 5 revealed that there is significant difference in the motivational packages available to junior and senior bank staff; $\mathrm{t}(148)=5.249, p>0.05$. Hence the null hypothesis is not accepted. This implies that the motivational packages, available to junior and senior bank staff differ. This could be as a result of their positions in banks, educational attainment and designation.

Hypothesis 2: There is no significant difference in workplace productivity of bank staff based on years of experience.

Table 6 revealed the difference in the workplace productivity of bank staff based on years of experience; $\mathrm{F}(3,146)=28.37, p<0.001$. Hence the null hypothesis is rejected. Therefore there is a significant difference in the workplace productivity of bank staff based on their years of experience. The table further reveals that staff within 1 - 5 years of experience $($ mean $=40.09)$ displayed the highest workplace productivity tendency. Followed by those staff within $6-10$ years of experience $($ mean $=36.47)$, those within $11-15$ years of experience $($ mean $=31.07)$ and the bank staff within $16-20$ years of experience $($ mean $=$ 26.66).This implies that staff within 1 - 5 yrs and 6 - 10 years of experience are more likely to display high productivity (that is, their mean value is above the grand mean $=34.1667)$.

Table 5. T-test showing difference in the motivational packages available to junior and senior bank staff.

\begin{tabular}{cccccccc}
\hline Groups & N & Mean & St. DV & Crit-t & Cal-value & df & P \\
\hline Senior Staff & 110 & 37.2133 & 10.06728 & 1.96 & 5.249 & $>0.05$ & \\
Junior Staff & 40 & 31.1200 & 10.03947 & & & 148 & 0.281 \\
\hline
\end{tabular}

Table 6. One Way ANOVA summary table showing differences in workplace productivity of bank staff based on years of experience.

\begin{tabular}{ccccccccc}
\hline $\begin{array}{c}\text { Years of } \\
\text { experiences }\end{array}$ & N & Mean & $\begin{array}{c}\text { Std. } \\
\text { Deviation }\end{array}$ & $\begin{array}{c}\text { Sum of } \\
\text { Squares }\end{array}$ & df & $\begin{array}{c}\text { Mean } \\
\text { Square }\end{array}$ & F & Sig. \\
\hline $1-5$ yrs & 41 & 40.0952 & 10.57346 & 7348.758 & 3 & 2449.586 & 28.373 & 0.000 \\
$6-10$ yrs & 55 & 36.4744 & 11.42761 & 25554.909 & 146 & 86.334 & & \\
$11-15$ yrs & 39 & 31.0741 & 5.48584 & 32903.667 & 149 & & & \\
$16-20$ yrs & 15 & 26.6667 & 8.25126 & & & & & \\
Total & 150 & 34.1667 & 10.49027 & & & & \\
\hline
\end{tabular}




\section{Conclusions}

This study has examined the effectiveness of motivational strategies on productivity in selected financial institutions in Oyo State, with reference to First Bank of Nigeria and Union Bank of Nigeria.

This result found that there is positive relationship between motivational strategies and employees' productivity. The result demonstrated that the financial strategies available to employees are leave allowances, bonus and fringe benefits paid when due, availability and accessibility of medical insurance, pension fund scheme and the non-financial strategies are promotion as at when due, training and friendly work environment contribute immensely to high productivity of employees. The finding indicated that motivational strategies have significant influence on productivity of workers as it makes worker put in their best always, management use it as a tool to motivate and increase productivity, influence workers attitude towards work done impact on the morale of workers and helps workers put in their best. The findings showed that the problems associated with motivational strategies are favourism, bad management, insincerity, motivational strategies are not properly provided and indiscriminate use of incentives to motivate workers. The findings showed that respondent agreed that management view motivational strategies as way to motivate junior staff, encourage workers to be committed to work, enhancing productivity. The finding revealed that there is significant difference in the motivational packages available to junior and senior bank staff the null hypothesis is not accepted. The finding also revealed the difference in the workplace productivity of bank staff based on years of experience. Hence the null hypothesis is rejected. From the study, motivational strategies are essential tools in enhancing productivity in the banking industry.

\section{Recommendations}

Based on the findings of this study the following recommendations were made:

- Management of these private enterprises are advised to plan very well when considering motivational strategies aimed at increasing productivity of the workers.

- To effectively handle the problems that emanate from productive capacity of workers, the management needs to improve salaries, benefit from time to time, organise training, re-training, and improve the working condition of workers.

- Also give a sense of recognition, belongingness, chance to contribute and flexibility in approaches to conflicts with the workers. The expectation of this review is to increase motivation and simultaneously induce greater productivity among worker.

- Employees' with longer years of experience (above 10 years) should be induced by the management with more motivational strategies for higher productivity.

- The management needs to periodically review the motivational packages 
available to staff.

\section{The Limitation and Suggestion for Further Studies}

The study is only limited to two banks at Ibadan head offices. This was due to time and financial constraints. Intending researchers can enlarge the scope to other branches of these banks as well as other banks. The study of motivation and productivity cannot be exhausted in a single study. Researchers can also carry out the study in other organizations such as government establishments and private enterprises.

\section{References}

[1] Tilgher, A. (1962) Work through the Ages. In: Nosow, S. and Form, W.H., Eds., Man Work and Society, Basic Books, Inc., New York.

[2] Omole, M.A.L. (1999) Industrial Education and Human Resources Development. ALAFAS Nigeria Company, Ibadan, 1-4.

[3] Guay, F., Chanal, J., Ratelle, C.F., Marsh, H.W., Larose, S. and Boivon, M. (2010) Intrinsic, Identified and Controlled Types of Motivation for School Subjects in Young Elementary School Children. British Journal of Educational Psychology, 80, 711-735. https://doi.org/10.1348/000709910X499084

[4] Gredler, M.E., Broussard, S.C. and Garrison, M.E.B. (2004) The Relationship between Classroom Motivation and Academic Achievement in Elementary School Aged Children. Family and Consumer Sciences Research Journal, 33, 106-120. https://doi.org/10.1177/1077727X04269573

[5] Deci, E.L., Koestner, R. and Ryan, R.M. (1999) A Meta-Analytic Review of Experiments Examining the Effects of Extrinsic Rewards on Intrinsic Motivation. Psychological Bulletin, 125, 627-668. https://doi.org/10.1037/0033-2909.125.6.627

[6] Okeke, C.P. (2010) The Impact of Job Satisfaction on Employee Performance in Government Owned Enterprises. Master Thesis, Department of Management, University of Nigeria, xix-xxi.

[7] George, N.R. (2012) Motivational Strategies in Business, New York, Buffalo. www.smallbusiness.chron.com/motivation-strategies-business-4636.html

[8] Singh, H., Motwani, J. and Kumar, A. (2000) A Review and Analysis of the State of the Art Research on Productivity Measurement. Industrial Management and DataSystems, 100, 234-241. https://doi.org/10.1108/02635570010335271

[9] Mojahed, S. (2005) A Project Improvement System for Effective Management of Construction Projects. Louisina State University Doctoral Dissertations, 1-7.

[10] Okenwa, C.P. (2009) Entrepreneurship Development: A Practical Approach. Onitsha Adson Educational Publishers, 66-68.

[11] Maslow, A. (1970) Motivation and Personality. 2nd Edition, Henper and Row Publisher, New York.

[12] Herzberg, F. (1964) The Motivation Hygiene Concept and Problems of Manpower. Personnel Administration.

[13] Vroom, V.H. (1964) Work and Motivation. John Wiley, New York, 258. 
Submit or recommend next manuscript to SCIRP and we will provide best service for you:

Accepting pre-submission inquiries through Email, Facebook, LinkedIn, Twitter, etc. A wide selection of journals (inclusive of 9 subjects, more than 200 journals)

Providing 24-hour high-quality service

User-friendly online submission system

Fair and swift peer-review system

Efficient typesetting and proofreading procedure

Display of the result of downloads and visits, as well as the number of cited articles Maximum dissemination of your research work

Submit your manuscript at: http://papersubmission.scirp.org/

Or contact ajibm@scirp.org 